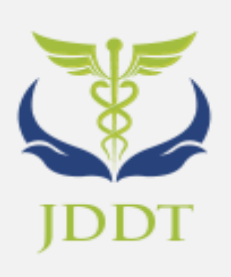

\title{
Pharmacological inVeStigation of LeAVES OF POLYPODIUM DECUMANUM FOR ANTIDIABETIC ACTIVITY
}

\author{
Pankaj Singh Niranjan"1, Dr. Chandrul Kaushal ${ }^{1}$, Dr. S.K. Jain ${ }^{2}$ \\ ${ }^{1}$ Shri Venkateshwara University, Gajroula, Uttar Pradesh, India \\ ${ }^{2}$ Institute of pharmacy, Bundelkhand University Jhansi, India
}

\section{ABSTRACT}

This research was performed to characterize the hypoglycemic effect of ethanolic extract of Polypodium decumanum leaves in alloxanized diabetic rats. The ethanolic extract of Polypodium decumanum leaves was administered orally at different doses (250 and $500 \mathrm{mg} \mathrm{kg}-1$ ) to normal rats. The dose of $500 \mathrm{mg} \mathrm{kg}-1$ was found to be more effective dose in oral route and it decreases Blood Glucose Level (BGL) by $22.2 \%$ in normal healthy rats after 14 days of administration. After daily treatment with the both dose (250 and $500 \mathrm{mg} \mathrm{kg}-1$ ) of ethanolic Polypodium decumanum extract for 21 days to severely Diabetic (FBG $300-350 \mathrm{mg}$ dL-1) rats, the BGL reduced to $128.2 \mathrm{mg} \mathrm{dL}-1$ by $250 \mathrm{mg} \mathrm{kg}-1$ and $111 \mathrm{mg} \mathrm{dL}-1$ by $500 \mathrm{mg} \mathrm{kg}-1$. The findings of our study indicate the hypoglycemic and potential antihyperglycemic nature of the extract. It is not similar effective when compared with the standard drug Glibenclamide, but quite effective in reducing BGL. It reduces blood glucose level up to $194.1,119.4,111 \mathrm{mg}$ dL-1 at successive days of 7, 14, 21, at the dose of $500 \mathrm{mg} \mathrm{kg-1}$ in rats compare with the standard drug which reduces blood glucose level up to 256.6, 140.7, $101.2 \mathrm{mg} \mathrm{dL}-1$. We found that the ethanolic extract of plant Polypodium decumanumleaves is only $10 \%$ less effective in reducing the BGL compare to standard drug (Glibenclamide).

Keywords: Polypodium decumanum, hypoglycemic effect, Glibenclamide

Article Info: Received 28 May, 2017; Review Completed 10 July, 2017; Accepted 11 July, 2017; Available online 15 July, 2017

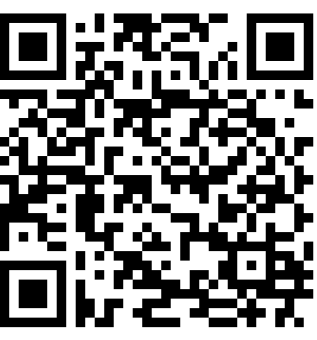

Cite this article as:

Niranjan PS, Kaushal C, Jain SK, Pharmacological investigation of leaves of polypodium decumanum for antidiabetic activity, Journal of Drug Delivery and Therapeutics. 2017; 7(4):69-72

DOI: http://dx.doi.org/10.22270/jddt.v7i4.1468

*Address for Correspondence

Pankaj Singh Niranjan, Shri Venkateshwara University, Gajroula, Uttar Pradesh, India.

Email: niranjanpankaj@yahoo.co.in

\section{INTRODUCTION}

Diabetes mellitus is a heterogeneous metabolic disorder as old as mankind and its incidence is considered to be high (4-5\%) all over the world ${ }^{1}$. Diabetes is a chronic disorder of carbohydrate, fat and protein metabolism characterized by elevation of both fasting and post-paradinal blood sugar levels. The synthetic oral hypoglycemic agents can produce serious side effects ${ }^{2,3}$. In addition they are not considered safe for use during pregnancy $^{4}$. Furthermore, after the recommendation made by ${ }^{5}$ on diabetes mellitus investigation on hypoglycemic agents from medicinal plants have become important. Plants have played a major role in the introduction to new therapeutic agents. A multitude of herbs, spices and other plant materials have been described for the treatment of diabetes throughout the world $^{6,7,8,9}$. The medicinal plants might provide a useful source of new oral hypoglycemic compounds for development of pharmaceutical entities or as a dietary adjunct to existing therapies ${ }^{10}$.Few of the plants used for the treatment of diabetes have received scientific or medical scrutiny and even the WHO expert committee on diabetes recommends that this area warrant further attention ${ }^{5}$. Despite the presence of known antidiabetic medicines in the pharmaceutical 
market, screening for new antidiabetic sources from natural plants is still attractive because they contain substances that have an alternative and safe effect on diabetes mellitus.

Polypodium Decumanum is terrestrial or epiphytic ferns with a creeping. The creeping rhizomes are 8-15 $\mathrm{mm}$ in diameter with the golden brown scales. They are densely hairy or scaly rhizome bearing fronds at intervals along its length. The species differ in size, general appearance and in the character of the fronds, which are evergreen, persisting for 1-2 years, pinnate (rarely simple) and about $10-80 \mathrm{~cm}$ long and $10-50 \mathrm{~cm}$ broad. It is having up to 35 pinnae with multiple colors from bright green to glaucous green with having undulate margins. Several round sori or groups of spore-cases (sporangia) are borne on the back of the frond and run along each side of the pinna midrib and the minute spores are wind dispersed. it has the ability to regulate and support the growth of various cells in the body including the skin and brain. It is most commonly used in traditional medical system to treat skin disorders and upper respiratory infection; however newer research discovered an even more useful ability. That is to protect the brain cells from damage.

Other uses of Polypodium Decumanum include treatment for vitiligo, kidney disease, cleansing the blood, an addition to detox formulation, improving and modulating the immune system, arthritis, and cancer. Polypodium Decumanum contains flavonoids, alkaloids and lipids. It is a rich source of lipids and fatty acids. The main plant chemicals identified in Samambaia includes adenosine, alkaloids, arachidonic acid, arabinopyranosides, calagualine, ecdysone, ecdysterone, eicosapentaenoic acid, elaidic acid, juglanin, kaempferols, linoleic acids, linolenic acids, melilotoside, oleic acid, ferulic acid, polypodaureine, ricinoleic acid, rutin, selligueain, and sulphoquinovosyl diacylglycerols.

\section{MATERIAL AND METHOD}

The Polypodium decumanum used in this study was procured from local market in indore and authenticated by Dr. D.K Srivastava, Scientist, College of Agriculture, ICAR division.

\section{Preparation of extract}

In the continuous hot extraction method the plant leaves extracted in Ethanol in 3 regular days at the temperature of $78-80^{\circ} \mathrm{C}$. The mixture was subsequently filtered and concentrated under reduced pressure at $40^{\circ} \mathrm{C}$. The extract yield was $26 \%$ w/w.

\section{Animal}

Albino mice 200-250 g obtained from Institute of Pharmacy, Bundelkhand University, Jhansi, India were housed in animal house (App. No. 716/02/a/CPCSEA) with $12 / 12 \mathrm{~h} \mathrm{light/dark}$ cycle at $21 \pm 2{ }^{0} \mathrm{C}$ and fed with laborator pellet chow and given water ad libitum. Animals were acclimatized to their environment for one week prior to experimentation. Investigations using experimental animals were conducted in accordance with the internationally accepted principles for laboratory animal use and care as found in the United
States Guidelines (United States National Institutes for Health Publication No. 85-23, revised in 1985) and our ethical committee on animal care approved the protocol.

\section{Induction of Diabetes in Mice}

After $15 \mathrm{~h}$ fasting mice were injected in intraperitoneally with alloxan monohydrate (Sigma chemical, USA) dissolved in sterile normal saline at a dose of $120 \mathrm{~kg}^{-1}$ body weight. To confirm diabetes, glycemia was daily determined after the administration of the last alloxan dose. Depending on their fasting blood glucose (FBG) level, the animals were divided arbitrarily in to two groups $^{9}$, mild diabetic (MD) animals with FBG of 120$250 \mathrm{mg} \mathrm{dl}^{-1}$, severaly diabetic (SD) animals showing FBG 250-300 $\mathrm{mg} \mathrm{dl}^{-1}$.

\section{Estimation}

Blood glucose level was estimated by using one touch Glucometer (Accu-chek censor) of Roche Diagnostic, Germany for regular check-up. Blood sample were collected from tail veins.

\section{Biological Assays \\ Oral glucose tolerance test (OGTT)}

Animals were fasted $18 \mathrm{hrs}$ before the day of experiment with free access to water and were separated in 5 groups of 10 rats each. Animals of all groups were treated with an oral D-glucose load of $2 \mathrm{gm} \mathrm{kg}^{-1}$ by means of cannula, group third and fourth were treated orally with ethanolic extract at a dose of $250 \mathrm{mg} \mathrm{kg}^{-1}$ b.w. and 500 $\mathrm{mg} \mathrm{kg}^{-1}$ b.w each for $30 \mathrm{~min}$ before the oral administration of oral glucose load. Control animals were treated with vehicle, blood sample were withdrawn from the cordal(tail) vein of each animals just after oral glucose administration $0 \mathrm{~min}, 30 \mathrm{~min}, 90 \mathrm{~min}$ and 120 min after glucose challenge and the fifth group received Glibenclamide (200 $\mathrm{mg} \mathrm{kg}^{-1}$ ) as positive control.

\section{Statistical analysis}

All biological results expressed as mean \pm SEM. Significant differences among the groups were determined by one-way analysis of variance (ANOVA) followed by Dunnett-t test. Statistical significance was considered at $\mathrm{P}<0.05$.

\section{RESULT}

The plant extract of Polypodium decumanum leaves (ethanolic extract) showed antidiabetic activity by reducing blood glucose level significantly. It is also much effective when compare with the standard drug Glibenclamide. It reduce blood glucose level up to 194.1, 119.4 and $111 \mathrm{mg} \mathrm{dl}^{-1}$ at successive days of $7,14,21$ at the dose of $500 \mathrm{mg} \mathrm{kg}^{-1}$ in rats compare with the standard drug which reduce blood glucose level up to 256.6,140.7 and 101.2. We found that the ethanolic extract of plant Polypodium decumanum leaves is 9-10 $\%$ less effective in reducing the blood glucose level compare to the standard drug (Glibenclamide).

\section{$\mathbf{L D}_{50}$}

The extract of the test substance (Polypodium decumanum) was found to be safe for further biological 
studies as no toxic effect and lethality was observed up to $3000 \mathrm{mg} \mathrm{kg}^{-1}$ per oral in mice. Only the consumption of food was increased by $20 \%$ in the dose of 2000 and
$3000 \mathrm{mg} \mathrm{kg} \mathrm{kg}^{-1}$ during $4 \mathrm{~h}$, but remaining normal afterwards.

Table 1: Effect of Polypodium decumanum leaves (Ethanolic extract) on body weight

\begin{tabular}{|l|c|c|c|c|}
\hline \multirow{2}{*}{ Treatment } & \multicolumn{4}{|c|}{ Body weight in gm } \\
\cline { 2 - 5 } & 1 day & 7 day & 14 day & 21 day \\
\hline Normal mice & $169 \pm 4.5$ & $170 \pm 4.9$ & $173 \pm 5.5$ & $178 \pm 5.4$ \\
\hline Control Diabetic Mice & $171 \pm 7.5$ & $156 \pm 8.5$ & $145 \pm 7.5$ & $139 \pm 7.3$ \\
\hline Diabetic Mice + PD I & $168 \pm 5.5^{*}$ & $161 \pm 5.5^{*}$ & $175 \pm 5.7^{*}$ & $180 \pm 5.6^{*}$ \\
\hline Diabetic Mice + PD II & $140 \pm 5.6^{*}$ & $133 \pm 7.5^{*}$ & $146 \pm 7.7^{*}$ & $159 \pm 7.8^{*}$ \\
\hline $\begin{array}{l}\text { Diabetic Mice + SD } \\
\text { (Glibenclamide) }\end{array}$ & $135 \pm 7.4^{*}$ & $142 \pm 8.6^{*}$ & $150 \pm 7.6^{*}$ & $165 \pm 6.5^{*}$ \\
\hline
\end{tabular}

(Values are mean \pm SEM, $(\mathrm{n}=5)^{*} \mathrm{p}<0.05$ when compare with control

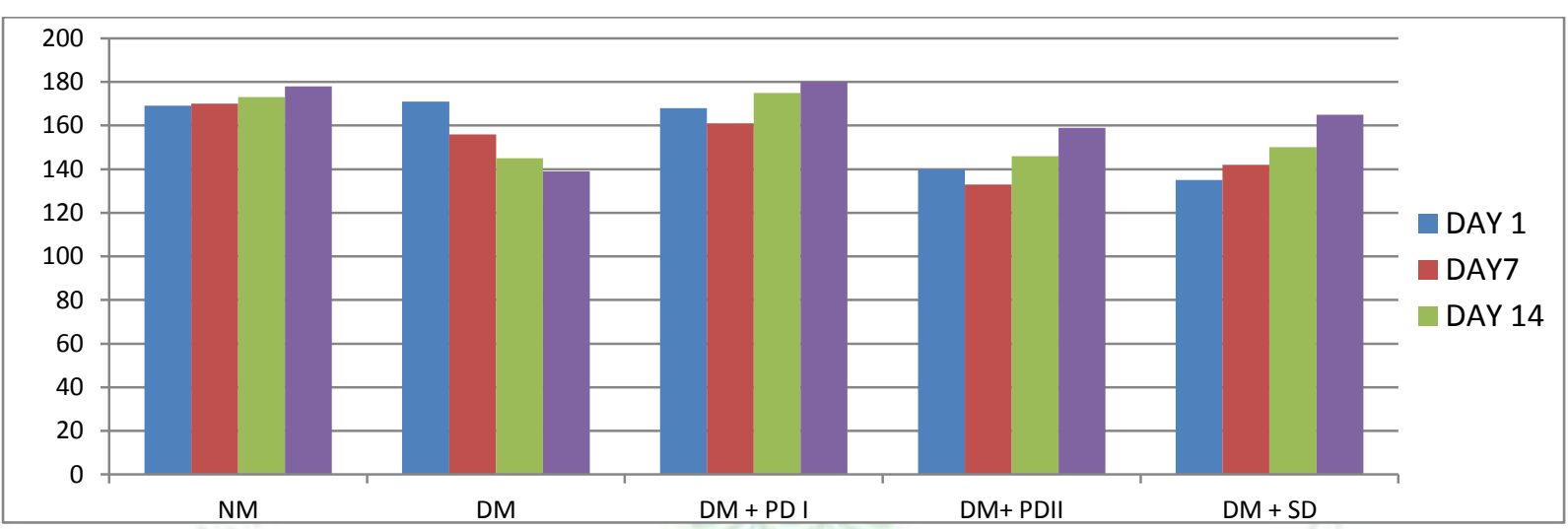

Figure 1: showing the effect of Polypodium decumanum plant extrat on body weight

Fig. Bar showing body weight of treated (extract of Polypodium decumanum) and non treated, normal and diabetic mice with the standard drug (Glibenclamide) at day 1,7,14 and 21 day of growth.(NM= normal mice, $\mathrm{DM}=$ diabetic mice, $\mathrm{PD}=\mathrm{Polypodium}$ decumanum plant extract)

Table 2: Effect of Polypodium decumanum (Ethanolic extract) on Blood Glucose Level (mg/dl)

\begin{tabular}{|l|c|c|c|c|}
\hline \multirow{2}{*}{ Treatment } & \multicolumn{4}{|c|}{ Blood glucose level } \\
\cline { 2 - 5 } & 1 day & 7 day & 14 day & 21 day \\
\hline Normal mice & $96.5 \pm 1.77$ & $95.0 \pm 2.56$ & $95.8 \pm 1.97$ & $94.7 \pm 2.01$ \\
\hline Control Diabetic Mice & $335.5 \pm 2.59$ & $317.6 \pm 2.78$ & $180.7 \pm 3.21$ & $133.3 \pm 2.10$ \\
\hline Diabetic Mice + PD I(250mg/kgBW) & $229.8 \pm 3.45^{*}$ & $209 \pm 3.90^{*}$ & $162.4 \pm 3.76^{*}$ & $128.2 \pm 2.87^{*}$ \\
\hline Diabetic Mice + PD II(500mg/kg BW & $224.2 \pm 2.53^{*}$ & $194.1 \pm 2.09^{*}$ & $139.4 \pm 3.21^{*}$ & $111 \pm 2.32^{*}$ \\
\hline Diabetic Mice + SD (Glibenclamide) & $309 \pm 7.4^{*}$ & $256.6 \pm 8.6^{*}$ & $140.7 \pm 7.6^{*}$ & $101.2 \pm 6.5^{*}$ \\
\hline
\end{tabular}

(values are mean \pm 7$),(\mathrm{n}=5)^{*} \mathrm{p}<0.05$ when compared with control

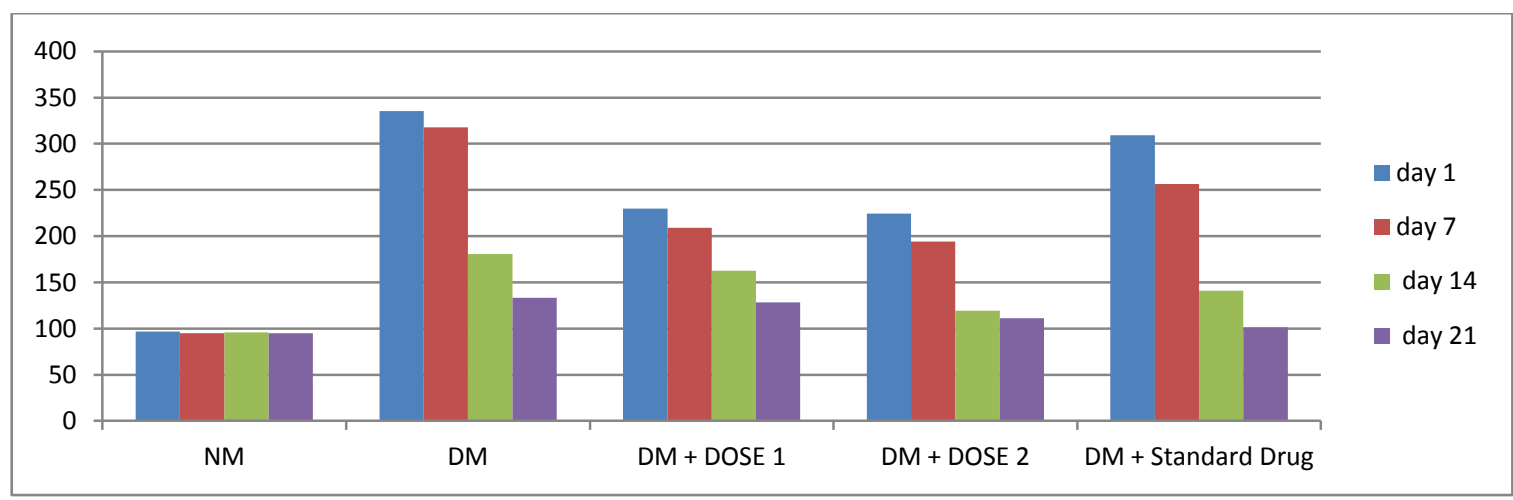

( $\mathrm{NM}=$ normal mice, $\mathrm{DM}=$ diabetic mice, dose $1=200 \mathrm{mg} / \mathrm{kg}$ b.w plant extract, dose $2=500 \mathrm{mg} / \mathrm{kg}$ b.wplant extract)

Figure 2: showing the effect of plant extract of Polypodium decumanum plant extract on blood glucose level 


\section{DISCUSSION}

The result showed important reduction of blood glucose level in healthy mice when administered the ethanolic extract of Polypodium decumanum extract by oral route. Ethanolic extract showed a dose-dependent effect on FBG up to a dose of $500 \mathrm{mg} \mathrm{kg}^{-1}$. After daily treatment with the dose $\left(250\right.$ and $\left.500 \mathrm{mg} \mathrm{kg}^{-1}\right)$ of ethanolic Polypodium decumanum extract for 21 days to severely diabetic (FBG 300-350 $\mathrm{mg} \mathrm{dl}^{-1}$ ) mice, the BGL reduced to $128.2 \mathrm{mg} \mathrm{dl}^{-1}$ and $111 \mathrm{mg} \mathrm{dl}^{-1}$ by 250 and $500 \mathrm{mg} \mathrm{kg}^{-1}$ respectively. The findings of our study indicate the hypoglycemic and potential antihyperglycemic nature of the extract. It is not as much effective when compare to standard drug but its effect quite significant because it reduce the BGL $194.1 \mathrm{mg} \mathrm{dl}^{-1}, 139 \mathrm{mg} \mathrm{dl}^{-1}$ and $111 \mathrm{mg}$ $\mathrm{dl}^{-1}$ with the dose of $500 \mathrm{mg} \mathrm{kg}{ }^{-1}$ at successive days of 7.14 and 21 of treatment with ethanolic extract of Polypodium decumanum. In the study on the effect of body weight the present study also showed that the body weight os the mice increased by 133, 146 and $159 \mathrm{gm}$ at the successive days of 7.14 and 21 when given the treatment of ethanolic extract of Polypodium decumanum at the dose of $500 \mathrm{gm} \mathrm{kg}^{-1}$ compare to standard drug Glibenclamide which increase the body weight by 142,150 and $165 \mathrm{gm}$ at the successive days of 7,14 and 21 . So we found that the plant extract increases the body weight significantly when given the plant extract dose $500 \mathrm{mg} \mathrm{kg}^{-1}$ when compare to $250 \mathrm{mg} \mathrm{kg}^{-1}$. Recently it is reported that extract of Polypodium decumanum leaves exhibit significantly radical scavenging activity and thus antioxidant activity and the present finding indicates that administration of extract of Polypodium decumanum leaves confirms the possibility that the major function of the extract is on the protection of vital tissues including the pancreas, thereby reducing the causation of diabetes in these animals. So protective effect of extract of Polypodium decumanum on alloxan induced diabetes mice could be attributed directly to scavenging activity and for more extent to the regeneration properties of the extract.

\section{CONCLUSION}

In conclusion our study indicates that extract of Polypodium decumanum produced antihyperglycemic effect in experimental diabetes by providing a regenerative modification against damage caused by alloxan to endocrine cells of the pancreas. The use of this plant in diabetes id the supported but the active substances and cellular and molecular mechanism(s) of this pharmacological effect are still to be determined.

\section{REFERENCES}

1. Akhtar M.S, and Iqbal J. "Evaluation of hypoglycemic effect of Achyranthes aspera in normal and alloxan diabetic rabbits", J. Ethnopharmacol.,1991; 31(1):49-57

2. Bailey L.J. and Day C. "Traditional plant medicine as treatment for diabetes",Diabetes Care., 1989; 12(8): 553-564

3. Gupta R.K., Kesari A.N, Murthy P.S., Chandra R., Tandon V, and Watal G, "Hypoglycemic and Antidiabetic Effect of Ethanolic Extract of leaves of Annona squamosa L. in Experimental Animals", J. Ethnopharmacolgy, 2005; 99(1):7581

4. Holman R.R. and Turner R.C. "Oral Agents and Insulin in the Treatment of NIDDM". In: Pickup J. and G. Williams (Eds.), Textbook of Diabetes, Blackwell, Oxford, 1991; 407-469.

5. Ivorra M.D, Paya M, and Villar A., "A review of natural products and plants as potential antidiabetic drugs", J. Ethnopharmacology, 1989; 27(3):243-275.

6. Kesari A.N., Gupta R.K., and watal G, "Hypoglycemic effect of Murraya koengii on normal and alloxan induced diabetic rabbits", J. Ethnopharmacol,2005; 97(2):247-251

7. Kumar N, Kshrisagr M.D, and Saini V. "GC-MS analysis of ethanolic extract of Polypodium decumanum", International journal of pharmacy, 2011; 2(9):155-156.

8. Larner J, “Insulin and Oral Hypoglycemic Drugs; Glucagon. In”: Gilman A.G., Goodman L.S., Rall T.W. and Murad F., (Eds.), The pharmacological Bases for Therapeutic. $7^{\text {th }}$ Edn, Macmillan, Newyork, 1985; 149-151.

9. Marles R.J, and Farnsworth N.R, "Antidiabetic plants and their active constituent", Phytomedicine, 1995; 2(12): 137-189.

10. Pickup J.C. and William G. "Epidemiology of Diabetes Mellitus", Textbook of Diabetes. 2nd Edn. Blackwell, Oxford, 1997; 3.1-3.28.

11. WHO, "Expert committee on Diabetes mellitus", technical reports series World Health Organisation, Geneva, 1980. 